\title{
Chronic Norepinephrine Elicits Desensitization by Uncoupling the $\beta$-Receptor
}

\author{
Dorothy E. Vatner, Stephen F. Vatner, Jun Nejima, Nobuhisa Uemura, Elena E. Susanni, \\ Thomas H. Hintze, ${ }^{\star}$ and Charles J. Homcy \\ Departments of Medicine and Pediatrics, Harvard Medical School, and the Cardiac Unit and Children's Service, Massachusetts \\ General Hospital, Boston, Massachusetts 02114; Brigham and Women's Hospital, Boston, Massachusetts 02115; \\ and The New England Regional Primate Research Center, Southborough, Massachusetts 01772
}

\begin{abstract}
The goal of this study was to determine the mechanism of $\beta$-adrenergic receptor desensitization after chronic elevation of circulating NE levels. Osmotic minipumps containing either NE or saline were implanted subcutaneously in dogs for 3-4 wk. Physiologic desensitization to isoproterenol was confirmed in conscious dogs, i.e., left ventricular $d P / d t$ increased in response to isoproterenol $(0.4 \mu \mathrm{g} / \mathrm{kg}$ per $\mathrm{min})$ by $5,625 \pm 731$ $\mathrm{mmHg} / \mathrm{s}$ in control dogs with saline pumps, and significantly less, $P<0.01$, by $2,093 \pm 263 \mathrm{mmHg} / \mathrm{s}$ in dogs with $\mathrm{NE}$ pumps. Myocardial $\beta$-adrenergic receptor density as determined with ${ }^{125}$ I-cyanopindolol binding was $49 \%$ higher ( $P$ $<0.05)$ in the NE pump group. However, $\beta$-adrenergic receptor agonist binding with isoproterenol demonstrated a significant shift into the low affinity state for the animals with NE pumps. Basal, GTP plus isoproterenol, 5'-guanylylimidodiphosphate, sodium fluoride, and forskolin-stimulated adenylate cyclase activity in the NE pump group were significantly depressed $(P<0.05)$ by amounts ranging from 20 to $40 \%$. The functional activity of the guanine nucleotide binding protein $\mathbf{G}_{\mathrm{s}}$ was also reduced $(P<0.05)$ in animals with $\mathrm{NE}$ pumps. Thus, the process of desensitization in response to chronic elevation of $\mathrm{NE}$ levels in intact, normal dogs does not involve a decrease in $\beta$-adrenergic receptor density. Rather, it is characterized by reduced adenylate cyclase activation and uncoupling of the $\beta$ adrenergic receptor in association with decreased activity of the GTP-coupling protein $\mathbf{G}_{\mathbf{s}}$.
\end{abstract}

\section{Introduction}

Catecholamine desensitization is thought to be involved in the pathogenesis of heart failure, a state that is characterized by elevated circulating levels of NE. The primary goal of the present investigation was to determine whether cardiac $\beta$-adrenergic receptor desensitization occurs after chronic elevation of circulating NE levels in normal animals. Although the phenomenon of catecholamine desensitization has been recognized for some time $(1,2)$ and has been examined repeatedly in vitro (3), relatively few studies have examined this phenomenon in vivo in a chronic model. The second goal of the pres-

Dr. Hintze is also affiliated with the Department of Physiology, New York Medical College, Valhalla, NY 10595.

Address correspondence to Dr. Dorothy E. Vatner, New England Regional Primate Research Center, One Pine Hill Drive, Southborough, MA 01772.

Received for publication 15 November 1988 and in revised form 23 June 1989.

J. Clin. Invest.

(c) The American Society for Clinical Investigation, Inc.

$0021-9738 / 89 / 12 / 1741 / 08 \$ 2.00$

Volume 84, December 1989, 1741-1748 ent investigation was to determine the mechanism of the desensitization, i.e., whether it involved downregulation of $\beta$ adrenergic receptor density or alterations at the level of receptor coupling and/or adenylate cyclase activation.

To study these questions, miniosmotic pumps containing saline or NE were implanted subcutaneously for 3-4 wk in normal dogs. Physiologic desensitization was examined by comparing responses to the $\beta$-adrenergic agonist, isoproterenol, in conscious dogs with either NE or saline pumps. The animals were then killed and cardiac sarcolemma was prepared and used to determine $\beta$-adrenergic receptor density and adenylate cyclase activity. Agonist competition curves were used to quantitate the percent of coupled receptors, i.e., those binding agonist with high affinity. Finally, using purified sarcolemma the functional level of $\mathrm{G}_{\mathrm{s}}$, the GTP-regulatory protein that couples the $\beta$-receptor to adenylate cyclase, was also measured.

\section{Methods}

26 adult mongrel dogs were anesthetized with sodium pentobarbital $(30 \mathrm{mg} / \mathrm{kg}$ ) and ventilated with a respirator (Harvard Apparatus Co. Inc., S. Natick, MA). Using sterile technique, and through an incision in the left fifth intercostal space, Tygon catheters (Norton Co., Akron, $\mathrm{OH})$ were implanted in the descending thoracic aorta and a solid-state pressure gauge (P22; Konigsberg Instruments, Inc., Pasadena, CA) was inserted into the left ventricle via an apical stab wound. The incision was closed in layers, the pneumothorax was reduced, and the animals were allowed to recover. After 3-4 wk of recovery and after control experiments were completed, anesthesia was induced with sodium thiamylal (6-8 mg/kg) and locally with lidocaine to implant a miniosmotic pump (Alza Corp., Palo Alto, CA) in the subcutaneous tissue. In 10 animals $2 \mathrm{ml}$ saline was placed in the pump, while in 16 animals $\mathrm{NE}$ was placed in the pump to infuse at a rate of $0.5 \mu \mathrm{g} / \mathrm{kg}$ per min over a 2-wk period. A second pump was implanted $10 \mathrm{~d}$ to $2 \mathrm{wk}$ after the first pump so that the duration of the chronically high NE levels was 3-4 wk (4). Plasma NE samples were drawn from the chronically implanted aortic catheter and levels were assayed weekly in animals with NE pumps to assure sustained high levels of NE.

Arterial pressure was measured using the implanted catheters and a P23 Db strain gauge manometer (Statham, Oxnard, CA). Left ventricular pressure was measured with the solid-state miniature pressure gauge and calibrated in vitro against a mercury manometer and in vivo against the arterial pressure measurement. In all 10 dogs with saline pumps and in 9 of the 16 dogs with NE pumps physiological desensitization was assessed in the conscious state by examining responses to isoproterenol challenges before and 3-4 wk after implantation of the pumps. The effects of acute challenges to isoproterenol, $0.1-0.4 \mu \mathrm{g} / \mathrm{kg}$ per min for $5 \mathrm{~min}$, were examined on measurements of left ventricular pressure and the rate of change of left ventricular pressure, $d P / d t$, an index of the inotropic state. To avoid the complicating effects of $\beta_{2^{-}}$ adrenergic receptor-mediated hypotension on the interpretation of the rate of change of left ventricular pressure in these experiments, phenylephrine was coinfused to maintain arterial pressure constant in animals with NE and saline pumps. The dose of phenylephrine, ranging 
from 1.6 to $8.0 \mu \mathrm{g} / \mathrm{kg}$ per min was not different in the two groups of animals. The data were recorded on a multichannel tape recorder and played back on a direct writing oscillograph.

At 1-4 d after physiological verification of desensitization the animals were anesthetized with sodium pentobarbital $(30 \mathrm{mg} / \mathrm{kg})$ and their hearts excised and placed in iced saline. The remaining seven dogs were killed at 3-4 wk after implantation of the NE pumps. The left ventricle and septum were weighed, trimmed of fat and connective tissue, minced, and homogenized in 4 vol of buffer $I(0.75 \mathrm{M} \mathrm{NaCl}$ and $10 \mathrm{mM}$ histidine, $\mathrm{pH} 7.5$ ) with a PT-20S polytron for $5 \mathrm{~s}$ at half speed. The homogenate was centrifuged at $14,000 \mathrm{~g}$ for $20 \mathrm{~min}$. The pellet was resuspended in buffer I, homogenized for $5 \mathrm{~s}$ at half speed, and centrifuged at $14,000 \mathrm{~g}$ for $20 \mathrm{~min}$. The pellet was homogenized and centrifuged as before. The pellet was resuspended in buffer II $(10 \mathrm{mM}$ $\mathrm{NaHCO}_{3}$ and $5 \mathrm{mM}$ histidine), homogenized for $30 \mathrm{~s}$ three times at half speed, and centrifuged at $14,000 \mathrm{~g}$ for $20 \mathrm{~min}$. The pellet was filtered through one layer of Japanese silk screen, size 12, and saved as the crude membranes. The supernatant was centrifuged at $44,000 \mathrm{~g}$ for $30 \mathrm{~min}$. The resulting pellet was resuspended in $10 \mathrm{ml}$ cold deionized water. An equal volume of $2.0 \mathrm{M}$ sucrose was then added. This was applied to a discontinuous sucrose density gradient and centrifuged at $170,000 \mathrm{~g}$ for $85 \mathrm{~min}$. The layer between the 0.6 - and $0.25-\mathrm{M}$ sucrose interfaces was removed and diluted in deionized water. The suspension was centrifuged at $170,000 \mathrm{~g}$ for $30 \mathrm{~min}$. The pellet was resuspended in $0.25 \mathrm{M}$ sucrose and stored at $-70^{\circ} \mathrm{C}$ as the purified sarcolemma (5).

All studies were performed in triplicate in the presence of Tris buffer (100 mM Tris, $1 \mathrm{mM}$ EGTA, and $5 \mathrm{mM} \mathrm{MgCl}_{2}, \mathrm{pH} 7.2$ ). $\beta$-Adrenergic receptor antagonist binding studies were performed using eight concentrations of $25 \mu \mathrm{l}^{125} \mathrm{I}$-cyanopindolol ( ${ }^{125} \mathrm{I}$-cyp) ${ }^{1}$ ranging from 0.02 to $1.0 \mathrm{nM}, 25 \mu \mathrm{l}$ isoproterenol $(0.1 \mathrm{mM})$, or buffer and $100 \mu \mathrm{l}$ of the crude membrane protein ( $10 \mu \mathrm{g} /$ assay). The antagonist binding data were analyzed by the "Ligand" program (6). A linear regression was performed on the amount bound vs. bound/free ligand. An $r^{2}$ value of 0.7 was the criterion used for acceptability of the data. Both crude and purified membrane sarcolemma preparations were used in this study because of the limited yield of the purified sarcolemma. Studies were performed with the crude membranes except for the $G_{s}$ labeling and reconstitution experiments, which require the enriched sarcolemmal preparation for optimal results; agonist-binding experiments were performed using both crude and purified membrane preparations. These preparations were shown to yield similar results in terms of high and low affinity states.

Competitive inhibition agonist binding curves were performed using $100 \mu \mathrm{l}$ of both the crude ( $10 \mu \mathrm{g} /$ assay) and purified sarcolemma $(0.5 \mu \mathrm{g} /$ assay $), 25 \mu \mathrm{l}{ }^{125} \mathrm{I}$-cyp $(0.1 \mathrm{nM}), 25 \mu \mathrm{l}$ isoproterenol $(0.1 \mathrm{mM}-0.1$ $\mathrm{nM}$ ) with 21 concentrations of isoproterenol/assay, and $25 \mu \mathrm{l} 5$ '-guanylylimidodiphosphate $(\mathrm{Gpp}[\mathrm{NH}] \mathrm{p} ; 0.1 \mathrm{mM})$ or buffer. The assays were performed using membranes from 7 dogs with saline pumps and 11 animals with NE pumps. Assays were incubated at $37^{\circ} \mathrm{C}$ for $30 \mathrm{~min}$, terminated by rapid filtration on GF/C filters (Whatman Laboratory Products Inc. Clifton, NJ), and counted in a gamma counter (TM Analytic, Inc., Elkgrove Village, IL) for $1 \mathrm{~min}$. Specific binding was $>80 \%$. The binding data were analyzed by the Ligand computer program of Munson and Rodbard (6). In the computer analysis the F test was used to compare the best fit for the ligand binding competition data. The best fit, two-site vs. one-site, was determined by the $P$ value for the $F$ test.

ADP ribosylation of $\mathrm{G}_{\mathrm{s}}$ by cholera toxin was determined in purified sarcolemma as previously described (7). Purified sarcolemma from nine dogs with saline pumps and nine dogs with NE pumps were also used for the reconstitution of $G_{s}$ into $S 49$ lymphoma cyc- membranes as described by Sternweis and Gilman (8). Cyc- membranes were prepared according to the method of Ross et al. (9). Reconstitution was performed over a wide range of solubilized sarcolemmal concentra-

1. Abbreviations used in this paper: cyp, cyanopindolol; $\mathrm{Gpp}(\mathrm{NH}) \mathrm{p}$, 5 '-guanylyl-imidodiphosphate; $\mathrm{G}_{\mathbf{s}}$, GTP = coupling protein; NE, norepinephrine.

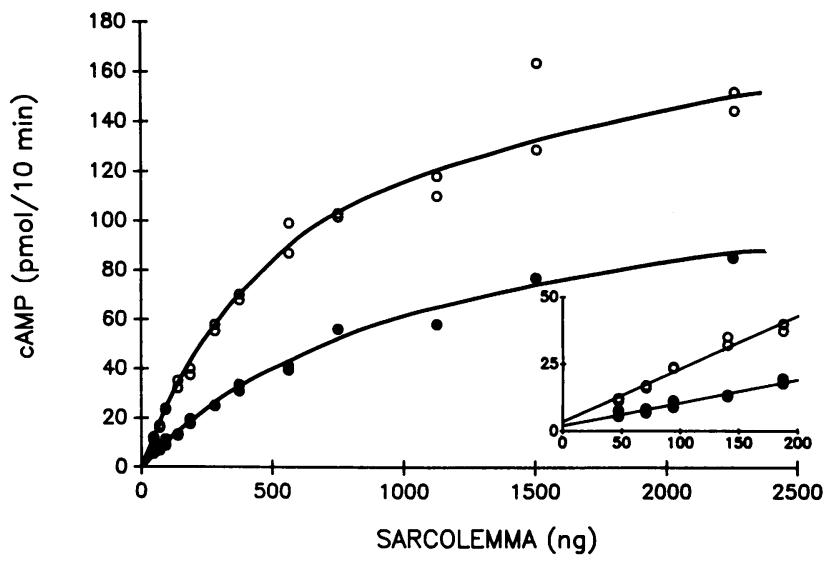

Figure 1. $\mathrm{G}_{\mathrm{s}}$ reconstitution data are shown over a wide range of sarcolemma protein concentrations (50-2,500 ng) for one animal in the saline pump group (open circles) and one animal in the NE pump group (solid circles). With increasing amounts of purified sarcolemma protein, $G_{s}$ from the animal with the pump stimulated less cAMP production than that from the animal with the saline pump. The inset shows the linear portion of the curve that was used for calculation of $\mathrm{G}_{\mathrm{s}}$ activity.

tions (50-2,500 ng) using a constant amount of cyc- membranes (Fig. 1). The protocol used a $2 \%$ cholate solution, which is optimal for $G$ protein solubilization. Using purified sarcolemma allows the cholate solution, which could inactivate the cyclase catalytic unit, to be highly diluted in Lubrol for the reconstitution assay. The activity of $G_{s}$ in reconstituting adenylate cyclase activity was measured as the slope of the curve where adenylate cyclase activity increases linearly with the amount of added sarcolemmal $G_{s}$. The activity of the reconstituted $G_{s}$ was linear from 0 to $300 \mathrm{ng}$ of sarcolemma. The initial portion of the relationship was assessed using linear regression analysis. To insure that the reconstitution assay was reproducible for quantitative comparisons, routine interassay controls were used with each new set of sarcolemma.

Tissue and plasma catecholamine levels were measured by the radioenzymatic assay of Peuler and Johnson (10). Sodium, potassium-ATPase activity was determined by the method of Jones and Besch (5). Protein levels were assayed by the method of Lowry et al. (11). Adenylate cyclase activity was assayed according to the method of Salomon et al. (12). Basal and maximal adenylate cyclase activity were measured using $0.1 \mathrm{mM}$ GTP, $0.1 \mathrm{mM} \mathrm{GTP}$ plus $0.1 \mathrm{mM}$ isoproterenol, $0.1 \mathrm{mM} \mathrm{Gpp}(\mathrm{NH}) \mathrm{p}, 10 \mathrm{mM}$ sodium fluoride, and $0.1 \mathrm{mM}$ forskolin.

$\beta$-Adrenergic receptor antagonist binding and adenylate cyclase activities were conducted in all animals; however, GTP plus isoproterenol stimulation was not examined in three of the animals. As the initial experiments indicated an increase in $\beta$-adrenergic receptor density and reduced adenylate cyclase activity, the later studies included hemodynamic measurements, $\beta$-adrenergic agonist binding, and measurement of $G_{s}$ activity.

Data were expressed as mean \pm SEM and stored in a PC-AT computer (IBM Instruments, Inc., Danbury, CT). Statistical evaluation was performed between the two groups using the $t$ test (13).

\section{Results}

Catecholamine levels. Circulating NE levels in the saline pump group were similar before and after the saline pump implantation ( $274 \pm 31$ vs. $255 \pm 33 \mathrm{pg} / \mathrm{ml})$. Plasma NE levels in the NE pump group were also similar in the animals before NE pump implantation $(220 \pm 42 \mathrm{pg} / \mathrm{ml})$. After NE pump implantation plasma NE levels were significantly increased and remained elevated at this level $(4,012 \pm 1,298 \mathrm{pg} / \mathrm{ml})$ for the remaining 
Table I. Baseline Values

\begin{tabular}{|c|c|c|c|c|}
\hline & \multicolumn{2}{|c|}{ Saline pumps } & \multicolumn{2}{|c|}{ NE pumps } \\
\hline & Before & After & Before & After \\
\hline $\begin{array}{l}\text { Left ventricular systolic } \\
\text { pressure }(\mathrm{mmHg})\end{array}$ & $123 \pm 3$ & $128 \pm 4$ & $121 \pm 2$ & $129 \pm 4$ \\
\hline $\begin{array}{l}\text { Left ventricular } d P / d t \\
\qquad(\mathrm{mmHg} / \mathrm{s})\end{array}$ & $2,946 \pm 160$ & $3,182 \pm 118$ & $3,001 \pm 222$ & $3,456 \pm 314$ \\
\hline $\begin{array}{l}\text { Mean arterial pressure } \\
\qquad(\mathrm{mmHg})\end{array}$ & $96 \pm 3$ & $98 \pm 5$ & $97 \pm 4$ & $92 \pm 3$ \\
\hline $\begin{array}{l}\text { Mean left atrial pressure } \\
(\mathrm{mmHg}) \\
\text { Heart rate (beats } / \mathrm{min})\end{array}$ & $\begin{array}{r}5 \pm 2 \\
94 \pm 4\end{array}$ & $\begin{array}{r}3 \pm 2 \\
92 \pm 5\end{array}$ & $\begin{array}{r}4 \pm 1 \\
91 \pm 6\end{array}$ & $\begin{array}{c}3 \pm 1 \\
76 \pm 5^{*}\end{array}$ \\
\hline
\end{tabular}

* $P<0.05$ difference between groups.

3-4-wk period. Left ventricular tissue NE levels were similar in the saline and NE pump groups ( $502 \pm 60$ vs. $492 \pm 76 \mathrm{pg} / \mathrm{mg}$ ).

Morphology. Animals in the saline pump group weighed $22 \pm 1.3 \mathrm{~kg}$, and animals in the NE pump group weighed $21 \pm 1.2 \mathrm{~kg}$. The left ventricle to body weight ratios were not significantly different between the two groups $(5.0 \pm 0.2 \mathrm{~g} / \mathrm{kg}$ for the animals with saline pumps, and $5.4 \pm 0.2 \mathrm{~g} / \mathrm{kg}$ for those with NE pumps).

Hemodynamics (Tables I and II). As shown in Table I, there were no significant differences in left ventricular pressure, left ventricular $d P / d t$, mean arterial pressure, and left atrial pressure between the two groups of dogs. Heart rate was lower $(P<0.05)$ after chronically elevated NE levels when compared with that in the dogs with saline pumps. Dose-response relationships to isoproterenol were examined in the two groups of animals before and after the pumps were implanted, with arterial pressure controlled. Isoproterenol increased heart rate less in the dogs with NE pumps than in the group of dogs with saline pumps (Table II). Physiological desensitization of left ventricular inotropy, i.e., left ventricular $d P / d t$, was observed in response to all dose levels of isoproterenol in the dogs with NE pumps (Fig. 2). For example, isoproterenol $(0.4 \mu \mathrm{g} / \mathrm{kg}$ per min) increased left ventricular $d P / d t$ significantly less $(P$ $<0.01$ ) in the animals with NE pumps (by $2,093 \pm 263$ $\mathrm{mmHg} / \mathrm{s})$ than observed in the control dogs $(5,625 \pm 731$ $\mathrm{mmHg} / \mathrm{s}$ ).

$\beta$-Adrenergic receptors. In the 16 dogs with NE pumps $\beta$ adrenergic receptor density in the left ventricle ( $94 \pm 9 \mathrm{fmol} /$ $\mathrm{mg})$ increased significantly $(P<0.05)$ as compared with the

Table II. Changes from Baseline in Response to Isoproterenol (0.4 $\mu \mathrm{g} / \mathrm{kg}$ per $\mathrm{min})$

\begin{tabular}{lccccc}
\hline & \multicolumn{2}{c}{ Saline pumps } & & \multicolumn{2}{c}{ NE pumps } \\
\cline { 2 - 3 } \cline { 5 - 6 } & Before & After & & Before & After \\
\hline $\begin{array}{c}\text { Left ventricular systolic } \\
\text { pressure }(m m H g) \\
\begin{array}{c}\text { Left ventricular } d P / d t \\
(m m H g / s)\end{array}\end{array}$ & $36 \pm 8$ & $42 \pm 8$ & & $33 \pm 6$ & $17 \pm 6^{*}$ \\
$\begin{array}{c}\text { Mean arterial pressure } \\
(m m H g)\end{array}$ & $4,610 \pm 563$ & $5,625 \pm 731$ & & $5,153 \pm 511$ & $2,093 \pm 263^{*}$ \\
Heart rate $($ beats $/$ min $)$ & $93 \pm 12$ & $103 \pm 8$ & & $90 \pm 10$ & $74 \pm 10^{*}$ \\
\hline
\end{tabular}

${ }^{*} P<0.05$ difference between groups.

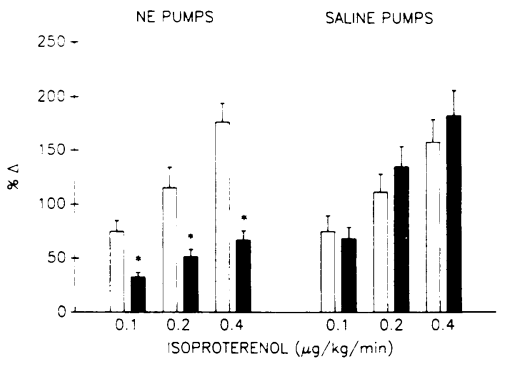

Figure 2. The effects of acute challenges to isoproterenol (0.1-0.4 $\mu \mathrm{g} / \mathrm{kg}$ per min) on left ventricular $d P / d t$ were examined before (open bars) and after (solid bars) implantation of the miniosmotic pumps. Animals with NE pumps are shown on the left, and animals with saline pumps are shown on the right. There is a significant decrease in responsiveness (desensitization) to isoproterenol in animals after implantation of the NE pumps. ${ }^{*} P$ $<0.05$.

dogs with saline pumps $(63 \pm 7 \mathrm{fmol} / \mathrm{mg}$; Fig. 3$)$. The $K_{d}$ for ${ }^{125}$ I-cyp was not significantly different between the two groups $(0.14 \pm 0.02 \mathrm{nM}$ in the control group and $0.17 \pm 0.02 \mathrm{nM}$ in the NE pump group).

In the seven animals studied with saline pumps the agonist binding data were best fit to a two-site model with a preponderance of receptors binding agonist with high affinity (Fig. 4). The $K_{\mathrm{i}}$ for the high affinity site was $53 \pm 11 \mathrm{nM}$ and the $K_{\mathrm{i}}$ for the low affinity site was $543 \pm 109 \mathrm{nM}$. In four animals $0.1 \mathrm{mM}$ $\mathrm{Gpp}(\mathrm{NH}) \mathrm{p}$ was added to the assay and in all cases induced a shift to a single low affinity site. In 9 of the 10 animals with NE pumps in which competition curves were performed, the agonist binding data in the absence of $\mathrm{Gpp}(\mathrm{NH}) \mathrm{p}$ were best fit to a single low affinity site model with a $K_{\mathrm{i}}$ of $353 \pm 120 \mathrm{nM}$. $\mathrm{Gpp}(\mathrm{NH}) \mathrm{p}$ did not induce any further shift in agonist affinity in the sarcolemma from these animals. In 1 of the 10 animals with NE pumps the agonist binding data in the absence of $\mathrm{Gpp}(\mathrm{NH}) \mathrm{p}$ were best fit to a two-site fit. On average $(n=10)$ the percent of $\beta$-adrenergic receptors binding agonist with high affinity was reduced in animals with NE pumps ( $3 \pm 3 \%$ ) com-

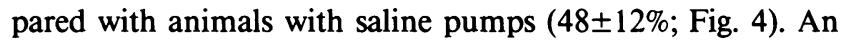
example of the shift in agonist binding using crude sarcolemma is shown in Fig. 5 and an example using purified sarcolemma in Fig. 6.

Adenylate cyclase activity (Table III). Adenylate cyclase activity was decreased significantly $(P<0.05)$ in the NE pump group as compared with the saline pump group. This included decreases in basal activity $(26 \%)$ and stimulated activities with

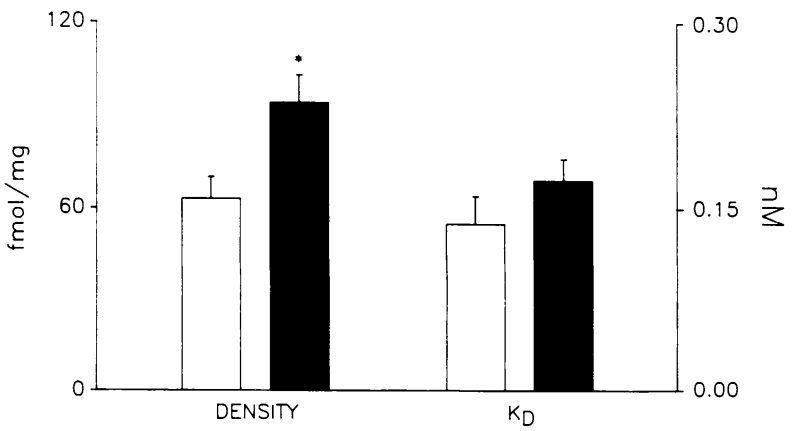

Figure 3. $\beta$-Adrenergic receptor density and $K_{\mathrm{d}}$ as determined by Scatchard analysis using ${ }^{125}$ I-cyp are shown for animals with saline pumps (open bars) and animals with NE pumps (solid bars). $\beta$-Receptor density is significantly increased $(P<0.05)$ in the animals with NE pumps as compared with animals with saline pumps. There is no difference in $K_{\mathrm{d}}$ between the two groups. ${ }^{*} P<0.05$. 


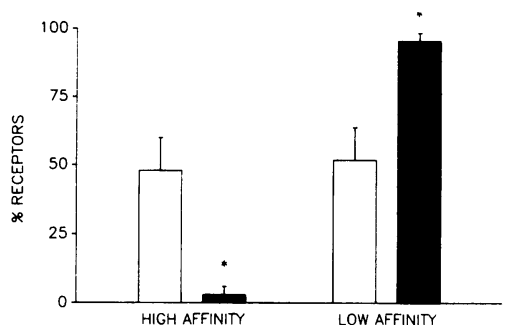

Figure 4. $\beta$-Adrenergic receptor competitive inhibition agonist binding with isoproterenol and ${ }^{125}$ I-cyp was performed for animals with saline pumps (open bars) and animals with $\mathrm{NE}$ pumps (solid bars). There is a significant shift toward the low affinity state for the animals with NE infusions. ${ }^{*} P<0.05$.

GTP plus isoproterenol (40\%), Gpp(NH)p (27\%), sodium fluoride $(20 \%)$, and forskolin (31\%). After subtracting basal activity, stimulated adenylate cyclase activity was still reduced in the NE group in response to GTP plus isoproterenol $(-43 \%, P$ $<0.001), \mathrm{Gpp}(\mathrm{NH}) \mathrm{p}(-28 \%, P<0.005)$, sodium fluoride $(-18 \%, P<0.14)$, and forskolin $(-31 \%, P<0.002)$.

Sodium, potassium-ATPase. As an index of the consistency of membrane preparation, the sarcolemmal marker, sodium, potassium-ATPase, was measured in the crude preparation and was not found to be significantly different in the two groups, i.e., $3.1 \pm 0.3 \mu \mathrm{mol} P_{\mathrm{i}} / \mathrm{h}$ per $\mathrm{mg}$ in the saline pump control group vs. $2.9 \pm 0.3 \mu \mathrm{mol} P_{\mathrm{i}} / \mathrm{h}$ per $\mathrm{mg}$ in the NE pump group. In the purified sarcolemma sodium, potassium-ATPase was $31 \pm 3.5 \mu \mathrm{mol} P_{\mathrm{i}} / \mathrm{h}$ per $\mathrm{mg}$ in the saline pump control group vs. $33 \pm 4.1$ in the NE pump group.

$G_{s}$ functional levels (Fig. 7). Reconstitution of $\mathrm{G}_{\mathrm{s}}$ into cycmembranes demonstrated depressed activity in the sarcolemma of animals with NE pumps as compared with the saline control group. Examples of entire reconstitution curves are shown in Fig. 1. The linear part of the relationship is depicted in the inset in Fig. 1. Linear regression of the slope was calculated for all animals studied and averaged $165 \pm 24 \mathrm{fmol} / \mathrm{ng}$ per $10 \mathrm{~min}$ in the NE pump group, which was lower $(P<0.05)$ than that observed in the saline pump group $(228 \pm 17 \mathrm{fmol} / \mathrm{ng}$ per $10 \mathrm{~min}$ ).

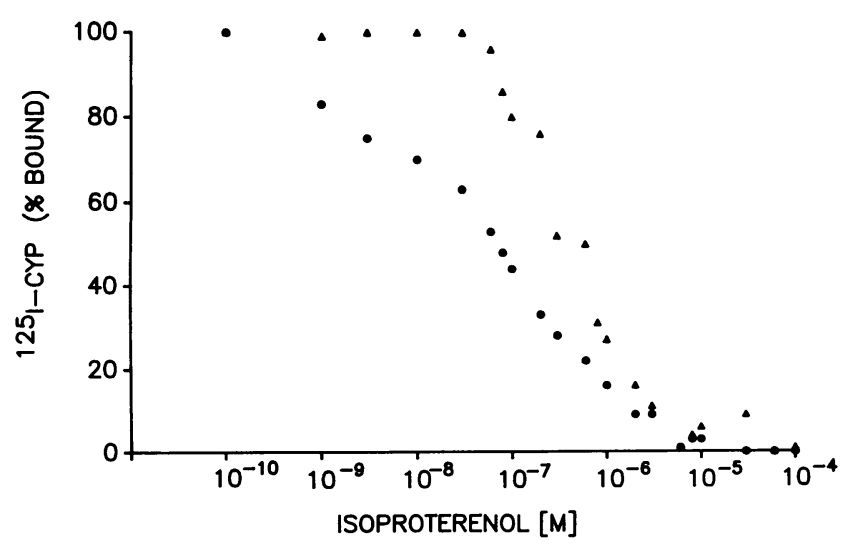

Figure 5. Isoproterenol agonist binding with the crude membrane preparation, and $0.1 \mathrm{nM}^{125} \mathrm{I}$-cyp with increasing concentrations of isoproterenol is shown for the left ventricle from an animal with a saline pump (circles) and an animal with a NE pump (triangles). The NE pump curve is shifted to the right, indicating a shift toward a single, low affinity site.

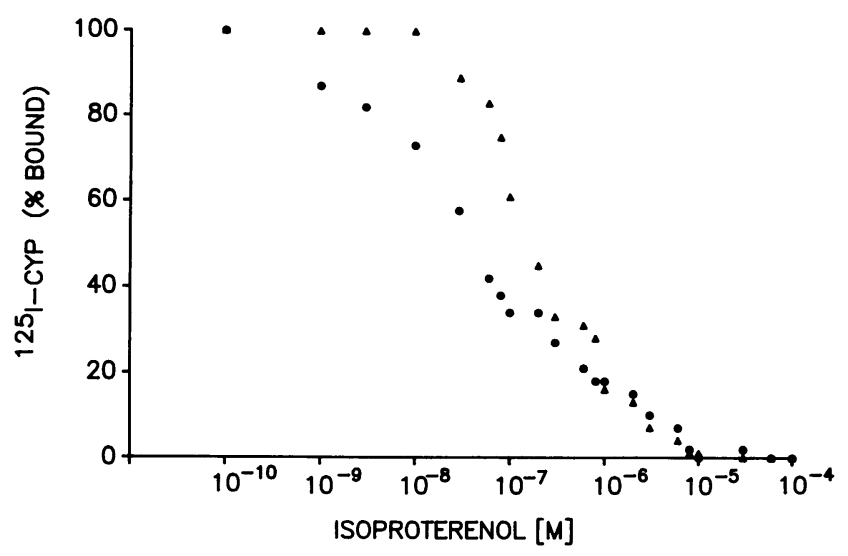

Figure 6. Isoproterenol agonist binding with the purified membrane preparation and $0.1 \mathrm{nM}^{125} \mathrm{I}$-cyp with increasing concentrations of isoproterenol is shown for the left ventricle from an animal with a saline pump (circles) and an animal with a NE pump (triangles). The NE pump curve is shifted to the right, indicating a shift toward a single, low affinity site.

$\mathrm{G}_{\mathrm{s}}$ protein levels, as determined by ADP ribosylation with cholera toxin, were significantly lower $(P<0.05)$ in the sarcolemma from dogs with NE pumps $(5.4 \pm 0.9 \mathrm{pmol} / \mathrm{mg})$ than the corresponding values for dogs with saline pumps $(10.3 \pm 1.7$ $\mathrm{pmol} / \mathrm{mg})$.

\section{Discussion}

The topic of desensitization has been studied extensively in isolated organ and cellular systems. These prior studies have demonstrated two primary mechanisms of desensitization, which have been referred to as homologous and heterologous (3, 14-16). Homologous desensitization is characterized by an attenuated responsiveness of adenylate cyclase only to the specific desensitizing hormone without affecting the enzyme's responsiveness to other hormones. In contrast, heterologous desensitization is characterized by diminished responsiveness of adenylate cyclase to a wide spectrum of activators, including other hormones as well as fluoride and guanine nucleotides. Still unanswered are the questions of whether desensitization

Table III. Adenylate Cyclase Activity (Picomoles/Milligram per Minute)

\begin{tabular}{lclc}
\hline & Saline pump & \multicolumn{1}{c}{$P$} & NE pump \\
\hline Basal & $118 \pm 8.0$ & $<0.010$ & $87 \pm 8$ \\
GTP & $171 \pm 11$ & $<0.02$ & $130 \pm 11$ \\
GTP + isoproterenol & $298 \pm 19$ & $<0.0001$ & $179 \pm 16$ \\
Gpp(NH)p & $525 \pm 31$ & $<0.002$ & $381 \pm 26$ \\
NaF & $428 \pm 33$ & $<0.05$ & $342 \pm 25$ \\
Forskolin & $1,205 \pm 71$ & $<0.001$ & $834 \pm 74$ \\
GTP - basal & $53 \pm 4$ & $<0.08$ & $43 \pm 4$ \\
GTP + isoproterenol - basal & $180 \pm 16$ & $<0.001$ & $103 \pm 11$ \\
Gpp(NH)p - basal & $407 \pm 28$ & $<0.005$ & $294 \pm 20$ \\
NaF - basal & $310 \pm 30$ & $<0.14$ & $255 \pm 18$ \\
Forskolin - basal & $1,087 \pm 68$ & $<0.002$ & $747 \pm 68$ \\
& & &
\end{tabular}




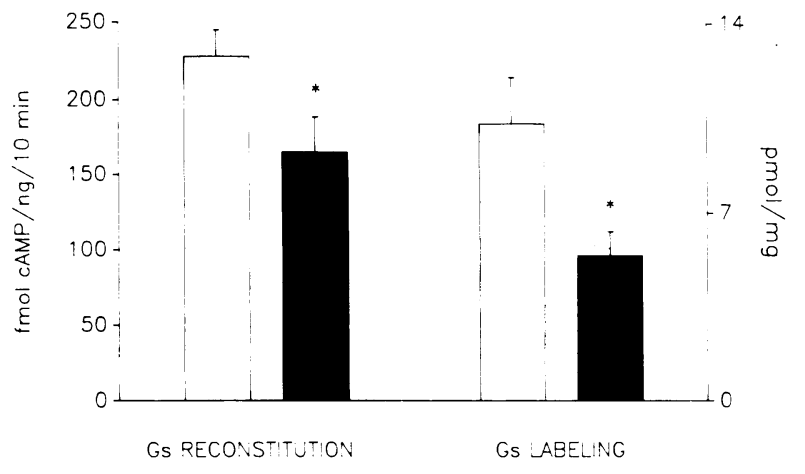

Figure 7. $\mathrm{G}_{\mathrm{s}}$ reconstitution data are summarized on the left and $\mathrm{G}_{\mathrm{s}}$ labeling with cholera toxin ADP-ribosylation is summarized on the right for the animals with saline pumps (open bars) and animals with NE pumps (solid bars). These data demonstrate a significant reduction in the levels of $\mathrm{G}_{\mathrm{s}}$ using both techniques. ${ }^{*} P<0.05$.

to NE is observed in chronic models, and if so, which type of desensitization is observed. This topic is clinically relevant in that several disease states, including heart failure, are characterized by chronically elevated levels of catecholamines.

Most prior studies, however, have been conducted in vitro and the majority have used isoproterenol $(3,14-16)$ rather than the physiological neurotransmitter NE to induce desensitization. The unique features of the present investigation were that the neurotransmitter NE was used and that the study was performed in an intact, conscious, large animal model using chronic infusions of NE delivered from implanted miniosmotic pumps. The major findings were: $(a)$ desensitization occurred as reflected by depressed inotropic responses to an isoproterenol challenge, and $(b)$ the mechanism of desensitization did not involve a decrease in $\beta$-adrenergic receptor density, but did involve uncoupling of the $\beta$-adrenergic receptor as reflected by decreases in the number of receptor sites binding agonist with high affinity. Accompanying this decrease in coupled or high affinity receptors was a decrease in $G_{s}$ activity as assessed by reconstitution as well as cholera toxin labeling. In addition, these changes were associated with decreases in basal and stimulated adenylate cyclase activation. Furthermore, adenylate cyclase activity was depressed in animals with $\mathrm{NE}$ pumps, whether stimulated through the $\beta$-adrenergic receptor or distally through the $G_{s}$ protein, a pattern consistent with a complex mechanism for desensitization. In contrast, the majority of prior studies on myocardial tissue have shown a specific (i.e., homologous) desensitization with an associated decrease in $\beta$-adrenergic receptor density $(3,14-16)$ and a loss of isoproterenol-stimulated adenylate cyclase activity, although a generalized decrease in adenylate cyclase activity has also been observed (17).

The defect or defects that explain the findings observed in this chronic model of catecholamine desensitization could reside in a single component or a combination of the three components of the receptor- $\mathrm{G}_{\mathrm{s}}$-adenylate cyclase pathway. In terms of alterations at the level of the $\beta$-adrenergic receptor, a surprising finding in the present investigation was that with chronically elevated NE levels $\beta$-adrenergic receptor density actually rose. The finding of increased $\beta$-adrenergic receptor density in the animals with chronic NE infusion may be secondary to the fact that as a physiological neurotransmitter the reuptake mechanism at the sympathetic nerve terminal may be acting to maintain low levels of NE at the postjunctional $\beta$-adrenergic receptor. Arterial baroreflex buffering of the peripheral effects of NE could also help reduce the actual concentration of $\mathrm{NE}$ at the postjunctional receptor site. Thus, it is possible that chronic occupancy by agonist at the myocyte $\beta$-receptor is actually reduced in this model and that the chronic desensitization to NE occurs via a different pathway than the homologous form elucidated by the work of Lefkowitz and colleagues and others in recent years $(3,18,19)$. Since isoproterenol has been used relatively acutely as the agonist in most prior studies of desensitization $(3,15,16,18,19)$, it is conceivable that homologous desensitization may be more compatible with acute exposure to isoproterenol.

The decrease in high affinity agonist binding and adenylate cyclase activation might be explained by the depressed functional levels of $G_{s}$. When $G_{s}$ activity was quantitated by reconstitution techniques its activity was found to be significantly lower over the entire range of sarcolemma protein in the left ventricle of NE-treated animals when compared with the saline pump group. Prior studies suggest that despite the high levels of $\mathrm{G}_{\mathrm{s}}$ in myocardium (i.e., a molar excess over $\beta$-receptor) its activity may be rate limiting in terms of either formation of the agonist high affinity or coupled state of the $\beta$-receptor, as well as in achieving maximal adenylate cyclase activation $(20,21)$. Recently we attempted to quantitate more exactly the absolute amount of $\mathrm{G}_{\mathrm{s}}$ by developing a standard curve for $G_{s}$ activity using a purified $G_{s}$ preparation whose specific activity was similar to that reported by Sternweis et al. (22). Based on such a standard curve, the levels of $G_{s}$ in purified canine sarcolemma are in the range of $25-30 \mathrm{pmol} / \mathrm{mg}$ membrane protein (unpublished data). That these levels were greater than those detected by cholera toxin labeling was expected in view of the less than quantitative nature of the latter method. This concentration of $\mathrm{G}_{\mathrm{s}}$ represents a 25 -fold excess over $\beta$-receptor and is similar to the results reported by Ransnas and Insel in the $\mathbf{S} 49$ lymphoma cell membrane (23). Despite this molar excess we observed a loss in formation of the high affinity $\beta$-receptor agonist binding state with a decrement in $\mathrm{G}_{\mathrm{s}}$ functional activity in this model of chronic desensitization as well as in a chronic heart failure model $(20,21)$. Parallel findings are observed in the membranes of patients with pseudohypoparathyroidism where $G_{s}$ levels are decreased to a similar extent (24). Whether the apparent excess of $G_{s}$ is associated with other membrane receptor/effector systems and thus functionally unavailable to couple with the $\beta$-receptor, or whether $G_{s}$ exists in discrete membrane domains and in effect is partitioned in the sarcolemma remains unanswered. Our present studies do not permit a determination as to whether the decrease in $\mathrm{G}_{\mathrm{s}}$ functional activity is secondary to a decrease in absolute subunit concentration and/or to a depressed functional activity of available $\mathrm{G}_{\mathrm{s}}$.

Our studies have not specifically addressed the question of whether the functional activity of the $\beta$-receptor and cyclase catalytic unit are normal. The work of Lefkowitz and coworkers (18) indicates that with agonist occupancy the $\beta$-receptor becomes susceptible to phosphorylation by a relatively specific kinase that they termed $\beta$-adrenergic receptor kinase. Thereafter, receptor uncoupling followed by internalization occurs. However, as discussed earlier, the increase in receptor number in this model might indicate that an increased level of 
occupancy by agonist is not occurring. Nevertheless, phosphorylation of the receptor leading to uncoupling might occur without a net loss of cell surface receptors. Evidence has been presented to suggest that the process of uncoupling and internalization are related but distinct $(25-28)$.

As to the third member of the $\beta$-adrenergic receptor signaling pathway, the catalytic unit of adenylate cyclase, our data indicate that all activators tested show a decreased stimulatory capacity. However, depression of cyclase activity in response to isoproterenol was most marked and in response to fluoride was least marked; i.e., after subtracting basal activity fluoridestimulated cyclase was still depressed, but not significantly. Although forskolin has been shown to activate the catalytic unit directly (29), other evidence indicates that its stimulation is enhanced in the presence of $\mathrm{G}_{\mathbf{s}}(30-35)$. Thus, the decreased levels of $G_{s}$ in the sarcolemma in the NE pump group could explain the reduced adenylate cyclase stimulation by forskolin. We attempted to assess the activity of the catalytic unit directly in two ways, but neither was definitive (unpublished data). Both manganese and manganese plus forskolin were used in an attempt to assay the catalytic unit when uncoupled from the $G$ protein. However, even in the presence of $20 \mathrm{mM}$ manganese we continued to observe $\mathrm{Gpp}(\mathrm{NH}) \mathrm{p}$-mediated stimulation of cyclase activity, indicating that complete uncoupling from $\mathrm{G}_{\mathrm{s}}$ had not occurred.

Since NE, which stimulates both $\alpha$ - and $\beta$-adrenergic receptors, was used as the agonist for desensitization, it is conceivable that $\alpha_{1}$-adrenergic receptor activation that leads to stimulation of protein kinase $\mathrm{C}$ may play a role in the desensitization observed in these studies. Yoshimasa and co-workers (36) have shown that protein kinase $C$ can phosphorylate the catalytic unit of adenylate cyclase in the frog erythrocyte. However, this led to an apparent enhancement of cyclase activity that would not explain the findings obtained in our study. Others have found, however, that phorbol ester-mediated stimulation of protein kinase $C$ can lead to desensitization of $\beta$-receptor-mediated stimulation of adenylate cyclase $(37,38)$. Thus, the question as to whether NE may ultimately exert an effect on the $\beta$-adrenergic receptor-adenylate cyclase pathway by activation of protein kinase C via $\alpha_{1}$-receptor stimulation remains a possibility. However, it must be kept in mind that the density of $\alpha_{1}$-adrenergic receptors in the canine heart is relatively low (39). In view of NE's role in stimulating baroreceptor reflex afferent and parasympathetic efferent pathways (40) it is also possible that muscarinic pathways may be involved in the mechanism of desensitization in response to chronic NE.

It is generally thought that catecholamine desensitization is an important mechanism involved in heart failure, a disease state characterized by chronic elevation in circulating catecholamine levels. In this connection there are several parallel features in a model of canine chronic left ventricular hypertrophy and heart failure $(20,21)$ and the present study. The model of heart failure is also characterized by a global depression in adenylate cyclase (20) and a reduction in $G_{s}(21)$. Moreover, in this canine model of heart failure, in contrast to studies in human heart tissue (41), $\beta$-adrenergic receptor density determined by antagonist binding is not reduced, although there is a marked reduction in $\beta$-adrenergic receptors that bind agonist with high affinity (20). The parallel findings in these two models, one of desensitization and the other of heart failure, provide support for the concept that the physiologic alter- ations might be attributed to the same underlying mechanism. However, the failing heart is associated with depletion of $\mathrm{NE}$ stores $(20,42)$, which is also observed in cardiac denervation (43). Under these conditions the reuptake mechanism and arterial baroreflexes might not be able to reduce the quantity of neurotransmitter at the postjunctional receptor site. In fact, in heart failure arterial pressure is generally reduced, which unloads the arterial baroreflexes and acts to increase sympathetic drive. In contrast, in the present investigation the dogs with NE pumps exhibited normal levels of myocardial catecholamines, and since arterial pressure was not elevated it is likely that arterial baroreflex buffering played a major role in the normalization of arterial pressure.

Another important parallel between the models of desensitization, hypertrophy, and heart failure is that chronic $\alpha$ adrenergic stimulation may induce left ventricular hypertrophy (44), and in fact has been observed by others in animals with chronic NE pumps (45). However, left ventricular weight/body weight ratios were not increased significantly in the present investigation, perhaps due to the period of time of NE stimulation (i.e., 3-4 wk). Accordingly, the present study does not support the possibility that the alterations in the $\beta$ adrenergic/adenylate cyclase pathway are due to the genetic and metabolic perturbations associated with the hypertrophic process per se. By converse logic the similar alterations in $\beta$-adrenergic receptor-adenylate cyclase activity and in the levels of $G_{s}$ that were observed in our studies of animals with hypertrophy and heart failure $(20,21)$ may not be due to the genetic and molecular alterations intrinsic to the hypertrophic process, but to other complications of the heart failure state, e.g., elevated circulating catecholamines.

In conclusion, this study identifies processes occurring distal to the $\beta$-receptor that are important in regulating the activity of the $\beta$-adrenergic receptor-adenylate cyclase pathway after chronic NE exposure. This process of desensitization involves a complex mechanism associated with a reduction in all aspects of stimulated adenylate cyclase activity, and despite most intense decreases in isoproterenol-stimulated adenylate cyclase activity there was no downregulation of $\beta$-adrenergic receptor density. Rather, uncoupling of the $\beta$-adrenergic receptor associated with decreased $\mathrm{G}_{\mathrm{s}}$ activity was observed. Potential alterations in the catalytic unit of adenylate cyclase and in the $\beta$-adrenergic receptor cannot be excluded. The failure to observe $\beta$-adrenergic receptor downregulation despite chronically elevated circulating NE levels may be unique to the intact, conscious animal model studied, in which arterial baroreflexes and neuronal uptake mechanisms act to reduce the concentration of $\mathrm{NE}$ at the postjunctional receptor site. This may result in noncoordinate regulation of $\mathrm{G}_{\mathrm{s}}$ and $\beta$-adrenergic receptors, which has been reported in other physiological models $(20,21,46)$. It is conceivable that in the absence of cardiac nerves or when an agent such as isoproterenol, which is not taken up by cardiac nerves, is used to elicit desensitization acutely, other mechanisms such as receptor downregulation may also play a role.

\section{Acknowledgments}

This work was supported in part by U. S. Public Health Service grants HL-37404, HL-19259, HL-38070, HL-33107, and RR-00168 from the Division of Research Resources, and Grants-in-Aid from the American Heart Association, Massachusetts Affiliate. Dr. D. E. Vatner is 
currently supported by U. S. Public Health Service Research Career Development Award HL-01909. Drs. Nejima, Uemura, and Susanni are supported by American Heart Association Massachusetts Affiliate fellowship awards.

\section{References}

1. Vigran, I. M., and H. E. Essex. 1950. Studies on physiologic effects of large doses of epinephrine. Am. J. Physiol. 162:230-242.

2. Essex, H. E. 1952. Further observations of certain responses of tolerant and control animals to massive doses of epinephrine. Am. J. Physiol. 171:78-86.

3. Harden, T. K. 1983. Agonist-induced desensitization of the $\beta$ adrenergic receptor-linked adenylate cyclase. Pharmacol. Rev. 35:5-32.

4. King, B. D., D. Sack, M. R. Kichuk, and T. H. Hintze. 1987. Absence of hypertension despite chronic marked elevations in plasma norepinephrine in conscious dogs. Hypertension (Dallas). 9:582-590.

5. Jones, L. R., and H. R. Besch, Jr. 1984. Isolation of canine cardiac sarcolemmal vesicles. Methods Pharmacol. 5:1-12.

6. Munson, P. J., and D. Rodbard. 1980. Ligand: a versatile computerized approach for characterization of ligand-binding systems. Anal. Biochem. 107:220-239.

7. Longabaugh, J. P., D. E. Vatner, R. M. Graham, and C. J. Homcy. 1986. NADP improves the efficiency of cholera toxin catalyzed ADP-ribosylation in liver and heart membranes. Biochem. Biophys. Res. Commun. 137:328-333.

8. Sternweis, P. C., and A. G. Gilman. 1979. Reconstitution of catecholamine-sensitive adenylate cyclase: reconstitution of the uncoupled variant of the $\mathbf{S 4 9}$ lymphoma cell. J. Biol. Chem. 254:33333340.

9. Ross, E. M., M. E. Maguire, T. W. Sturgill, R. L. Biltonen, and A. G. Gilman. 1977. Relationship between the $\beta$-adrenergic receptor and adenylate cyclase. J. Biol. Chem. 252:5761-5775.

10. Peuler, J. D., and G. A. Johnson. 1977. Simultaneous single isotope radioenzymatic assay of plasma norepinephrine, epinephrine, and dopamine. Life Sci. 21:625-636.

11. Lowry, O. H., N. J. Rosebrough, A. L. Farr, and R. J. Randall. 1951. Protein measurement with Folin phenol reagent. J. Biol. Chem. 193:265-275.

12. Salomon, Y., C. Londos, and M. Rodbell. 1974. A highly sensitive adenylate cyclase assay. Anal. Biochem. 58:541-548.

13. Armitage, P. 1975. Statistical Methods in Medical Research. Blackwell Scientific Publications Ltd., Oxford, UK. 205-207.

14. Sibley, D. R., K. Daniel, C. D. Strader, and R. J. Lefkowitz. 1987. Phosphorylation of the $\beta$-adrenergic receptor in intact cells: relationship to heterologous and homologous mechanisms of adenylate cyclase desensitization. Arch. Biochem. Biophys. 258:24-32.

15. Hertel, C., and J. P. Perkins. 1984. Receptor-specific mechanisms of densensitization of $\beta$-adrenergic receptor function. Mol. Cell. Endocrinol. 37:245-256.

16. Lefkowitz, R. J., J. M. Stadel, and M. G. Caron. 1983. Adenylate cyclase-coupled beta-adrenergic receptors: structure and mechanisms of activation and desensitization. Annu. Rev. Biochem. 52:159186.

17. Tse, J., J. R. Powell, C. A. Baste, R. E. Priest, and J. F. Kuo. 1979. Isoproterenol-induced cardiac hypertrophy: modifications in characteristics of $\beta$-adrenergic receptor, adenylate cyclase, and ventricular contraction. Endocrinology. 105:246-255.

18. Sibley, D. R., R. H. Strasser, M. G. Caron, and R. J. Lefkowitz. 1985. Homologous desensitization of adenylate cyclase is associated with phosphorylation of the $\beta$-adrenergic receptor. J. Biol. Chem. 260:3883-3886.

19. Strasser, R. H., and R. J. Lefkowitz. 1985. Homologous desensitization of $\beta$-adrenergic receptor coupled adenylate cyclase: resensitization by polyethelene glycol treatment. J. Biol. Chem. 260:45614564.
20. Vatner, D. E., S. F. Vatner, A. M. Fujii, and C. J. Homcy. 1985. Loss of high affinity cardiac $\beta$-adrenergic receptors in dogs with heart failure. J. Clin. Invest. 76:2259-2264.

21. Longabaugh, J. P., D. E. Vatner, S. F. Vatner, and C. J. Homcy. 1988. Decreased stimulatory guanosine triphosphate binding protein in dogs with pressure-overload left ventricular failure. J. Clin. Invest. $81: 420-424$.

22. Sternweis, P. C., J. K. Northup, M. D. Smigel, and A. G. Gilman. 1981. The regulatory component of adenylate cyclase. J. Biol. Chem. 256:11517-11526.

23. Ransnas, L. A., and P. A. Insel. 1988. Quantitation of the guanine nucleotide binding regulatory protein $\mathrm{G}_{\mathrm{s}}$ in $\mathrm{S} 49$ cell membranes using antipeptide antibody to $\alpha_{\mathrm{s}}$. J. Biol. Chem. 263:94829485.

24. Heinsimer, J. A., A. O. Davies, R. W. Downs, M. A. Levine, A. M. Spiegel, M. K. Drezner, A. DeLean, K. A. Wreggett, M. G. Caron, and R. J. Lefkowitz. 1984. Impaired formation of $\beta$-adrenergic receptor-nucleotide regulatory protein complexes in pseudohypoparathyroidism. J. Clin. Invest. 73:1335-1343.

25. Bouvier, M., W. P. Hausdorf, A. De Blasi, B. F. O’Dowd, B. K. Kobilka, M. G. Caron, and R. J. Lefkowitz. 1988. Removal of phosphorylation sites from the $\beta_{2}$-adrenergic receptor delays onset of agonist-promoted desensitization. Nature (Lond.). 333:370-373.

26. Clark, R. B., J. Friedman, J. A. Johnson, and M. W. Kunkel. 1987. $\beta$-Adrenergic receptor desensitization of wild-type but not cyc lymphoma cells unmasked by submillimolar $\mathrm{Mg}^{2+}$. FASEB (Fed. Am. Soc. Exp. Biol.) J. 1:289-297.

27. Kassis, S., M. Olasmaa, M. Sullivan, and P. H. Fishman. 1986. Desensitization of the $\beta$-adrenergic receptor-coupled adenylate cyclase in cultured mammalian cells: receptor sequestration versus receptor function. J. Biol. Chem. 261:12233-12237.

28. Boege, F., M. Ward, R. Jürss, M. Hekman, and E. J. M. Helmreich. 1988. Role of glycosylation for $\beta_{2}$-adrenoceptor function in A431 cells. J. Biol. Chem. 263:9040-9049.

29. Seamon, K. B., W. Padgett, and J. W. Daly. 1981. Forskolin: unique diterpene activator of adenylate cyclase in membranes and in intact cells. Proc. Natl. Acad. Sci. USA. 78:3363-3367.

30. Seamon, K. B., and J. W. Daly. 1981. Activation of adenylate cyclase by the diterpene forskolin does not require the guanine nucleotide regulatory protein. J. Biol. Chem. 256:9799-9801.

31. Wong, S. K.-F., and B. R. Martin. 1983. The role of a guanine nucleotide-binding protein in the activation of rat liver plasma-membrane adenylate cyclase by forskolin. Biochem. J. 216:753-759.

32. Downs, R. W., and G. D. Aurbach. 1982. The effects of forskolin on adenylate cyclase in S49 wild type and cyc- cells. J. Cyclic Nucleotide Res. 8:235-242.

33. Zahler, W. L. 1983. Evidence for multiple interconvertible forms of adenylate cyclase detected by forskolin activation. J. Cyclic Nucleotide Protein Phosphorylation Res. 9:221-230.

34. Stengel, D., L. Guenet, M. Desmier, P. Insel, and J. Hanoune. 1982. Forskolin requires more than the catalytic unit to activate adenylate cyclase. Mol. Cell. Endocrinol. 28:681-690.

35. Green, D. A., and R. B. Clark. 1982. Direct evidence for the role of the coupling proteins in forskolin activation of adenylate cyclase. J. Cyclic Nucleotide Res. 8:337-346.

36. Yoshimasa, T., D. R. Sibley, M. Bouvier, R. J. Lefkowitz, and M. G. Caron. 1987. Cross-talk between cellular signalling pathways suggested by phorbol-ester-induced adenylate cyclase phosphorylation. Nature (Lond.). 327:67-70.

37. Sibley, D. R., P. Nambi, J. R. Peters, and R. J. Lefkowitz. 1984. Phorbol diesters promote $\beta$-adrenergic receptor phosphorylation and adenylate cyclase desensitization in duck erythrocytes. Biochem. Biophys. Res. Commun. 121:973-979.

38. Kelleher, D. J., J. E. Pessin, A. E. Ruoho, and G. L. Johnson. 1984. Phorbol ester induces desensitization of adenylate cyclase and phosphorylation of the $\beta$-adrenergic receptor in turkey erythrocytes. Proc. Natl. Acad. Sci. USA. 81:4316-4320.

39. Shen, Y. T., D. E. Vatner, H. E. Gagnon, and S. F. Vatner. 
1989. Species differences in regulation of $\alpha$-adrenergic receptor function. Am. J. Physiol. 257 (Regulatory Integrative Comp. Physiol. 26):R1110-R1116.

40. Vatner, S. F., J. D. Rutherford, and H. R. Ochs. 1979. Baroreflex and vagal mechanisms modulating left ventricular contractile responses to sympathomimetic amines in conscious dogs. Circ. Res. 44:195-207.

41. Bristow, M. R., R. Ginsburg, W. Minobe, R. S. Cubicciotti, W. S. Sageman, K. Lurie, M. E. Billingham, D. C. Harrison, and E. B. Stinson. 1982. Decreased catecholamine sensitivity and $\beta$-adrenergicreceptor density in failing human hearts. N. Engl. J. Med. 307:205211.

42. Chidsey, C. A., E. Braunwald, and A. G. Morrow. 1965. Catecholamine excretion and cardiac stores of norepinephrine in congestive heart failure. Am. J. Med. 39:442-451.
43. Vatner, D. E., M. Lavallee, J. Amano, A. Finizola, C. J. Homcy, and S. F. Vatner. 1985. Mechanisms of supersensitivity to sympathetic amines in the chronically denervated heart of the conscious dog. Circ. Res. 57:55-64.

44. Simpson, P. 1985. Stimulation of hypertrophy of cultured neonatal rat heart cells through an $\alpha_{1}$-adrenergic receptor and induction of beating through an $\alpha_{1}$ and $\beta_{1}$-adrenergic receptor interaction. Circ. Res. 56:884-894.

45. Laks, M. M., F. Morady, and H. J. C. Swan. 1973. Myocardial hypertrophy produced by chronic infusion of subhypertensive doses of norepinephrine in the dog. Chest. 64:75-78.

46. Hammond, H. K., L. A. Ransnas, and P. A. Insel. 1988. Noncoordinate regulation of cardiac Gs protein and $\beta$-adrenergic receptors by a physiological stimulus, chronic dynamic exercise. J. Clin. Invest. 82:2168-2171. 